\title{
Penerapan Sistem Pertanian Organik dengan Aplikasi Pupuk Organik Cair Urin Kelinci pada Padi Sawah
}

\section{Implementation of Organic Farming System with Rabbit Urine Liquid Organic Fertilizer in Lowland Rice}

\author{
Yugi Rahayu Ahadiyat*, Ida Widiyawati, Ahmad Fauzi \\ Laboratorium Agroekologi, Jurusan Agroteknologi, Fakultas Pertanian, Universitas Jenderal Soedirman, Jl. Dr. Soeparno \\ No.61 Karangwangkal, Purwokerto, Jawa Tengah, 53123 \\ *Penulis Korespondensi: ahadiyat.yugi@unsoed.ac.id \\ Diterima Desember 2020/DisetujuiJuli 2021
}

\begin{abstract}
ABSTRAK
Kelompok tani Ngudi Tani merupakan salah satu kelompok tani yang ada di Kelurahan Bobosan, Kecamatan Purwokerto Utara, Kabupaten Banyumas. Lahan sawah yang berada di wilayah kelurahan Bobosan memiliki kondisi selalu tersedia air sepanjang tahun, namun budi daya padi yang dilakukan belum menerapkan sistem pertanian yang ramah lingkungan. Pupuk Organik Cair (POC) urin kelinci yang mengandung tambahan buah maja bisa digunakan sebagai substitusi pupuk dan pestisida sintetis. Tujuan kegiatan pengabdian ini adalah untuk meningkatkan pemahaman dan pengetahuan tentang sistem pertanian organik dengan aplikasi POC pada tanaman padi sawah dan cara pembuatan POC urin kelinci. Metode kegiatan yang dilakukan melalui penyuluhan dan pelatihan yang berhubungan dengan aplikasi POC pada pada sawah dan pembuatan POC urin kelinci. Demplot difokuskan pada cara kerja dan teknik yang benar dalam mendukung produksi padi melalui aplikasi POC urin kelinci. Kegiatan pengabdian melalui penyuluhan, pelatihan, demplot, dan introduksi ternak berhasil dengan baik meskipun belum melibatkan semua anggota kelompok tani. Pengetahuan dan keterampilan petani meningkat terkait budi daya kelinci dan pengolahan urin menjadi pupuk organik cair serta aplikasinya pada padi sawah. Introduksi POC urin kelinci pada budi daya padi sawah direspons positif oleh sebagian anggota kelompok tani dan petani telah memahami prosedur pengolahan limbah urin kelinci menjadi pupuk organik cair dan aplikasinya pada tanaman padi.
\end{abstract}

Kata kunci: padi sawah, pertanian organik, pupuk organik cair, urin kelinci

\begin{abstract}
The Ngudi Tani farmer group is one of the farmer groups in Bobosan Village, North Purwokerto District, Banyumas Regency. The rice fields in the Bobosan village area have irrigation system and the water is always available throughout the year, however rice farming has not been applied environmentally friendly agricultural system yet. Liquid Organic Fertilizer (LOF) of urine rabbit with quince bengal fruit could apply as substitution of fertilizer and pesticide synthetics.The purpose of this service activity was to increase understanding and knowledge about organic farming systems with the application of LOF in lowland rice and how to make rabbit urine LOF. Methods of activities were carried out through counseling and training related to LOF application in rice fields and makes use of rabbit urine LOF. The rice field plot was focused on the appropriate way of working and techniques in supporting rice production through the application of rabbit urine LOF. Counseling, training, demonstration plots and rabbit livestock introduction is successful even though not to all members of the farmer groups. The knowledge and skills of farmers have increased regarding rabbit livestock and processing of urine into liquid organic fertilizer and its application to lowland rice. The introduction of rabbit urine LOF in lowland rice cultivation has been responded positively by some members of farmer groups and farmers have understood the procedure for processing rabbit urine waste into liquid organic fertilizer and its application in rice plants.
\end{abstract}

Keywords: Liquid organic fertilizer, lowland rice, organic farming, rabbit urine

\section{PENDAHULUAN}

Kelurahan Bobosan merupakan salah satu kelurahan di wilayah Purwokerto, Kabupaten Banyumas berada pada ketinggian tempat 102,48 m dpl. Lahan sawah yang berada di wilayah Kelurahan Bobosan mencapai 83 ha merupakan sawah beririgasi semi teknis bersumber dari aliran mata air Gunung Slamet yang selalu tersedia sepanjang tahun. Produktivitas lahan 
sawah dengan karakteristik agroklimat demikian memang tidak terlalu tinggi dibanding produktivitas lahan sawah di daerah hilir. Selain itu, hamparan lahan sawah yang sempit, diselingi ragam penggunaan lahan lain seperti kolam, pemukiman, dan kebun campuran, menjadikan budi,daya padi di lahan tersebut selalu terkendala serangan OPT khususnya tikus dan burung. Hal ini menjadi permasalahan bagi petani Bobosan untuk berkembang.

Permasalahan lain adalah pendapatan yang tidak sebanding dengan modal sementara desakan pengembangan wilayah perkotaan kian pesat menjadi ancaman terjadinya konversi lahan pertanian menjadi non pertanian dan peralihan profesi dari petani menjadi nonpetani. Konversi lahan yang menjadikan semakin menyusutnya lahan pertanian akan mengganggu keseimbangan produksi pangan disamping menurunkan kualitas lingkungan hidup.

Salah satu upaya untuk mengatasi permasalahan tersebut adalah dengan meningkatkan pendapatan petani melalui sistem budi daya padi organik. Peningkatan pendapatan ini diharapkan tercapai melalui efisiensi usaha tani dan penambahan nilai jual produk padi organik. Budi daya padi organik adalah teknik budi daya padi yang mengandalkan bahanbahan alami tanpa menggunakan bahan-bahan kimia sintetis. Sistem budi daya padi organik terbukti mampu menghasilkan produksi padi yang optimal dan secara ekonomi lebih menguntungkan (Supartha et al. 2012; Lesmana \& Margareta 2017; Ahadiyat et al. 2019). Tujuan utamanya adalah menyediakan produk beras yang aman bagi kesehatan produsen dan konsumennya serta tidak merusak lingkungan. Penyediaan produk beras organik memiliki prospek yang sangat baik karena gaya hidup sehat telah melembaga secara internasional yang mensyaratkan jaminan bahwa produk pertanian harus beratribut aman dikonsumsi, kandungan nutrisi tinggi, dan ramah lingkungan. Preferensi konsumen seperti ini dan perkembangan ekonomi menyebabkan permintaan produk pertanian organik dunia meningkat pesat (Mayrowani 2016).

Selain berorientasi pada keamanan produk, keunggulan sistem pertanian organik adalah mampu memperbaiki karakteristik sifat fisik tanah, yaitu warna tanah menjadi kehitaman, mampu menurunkan bulk density tanah, meningkatkan total ruang pori tanah, dan meningkatkan permeabilitas tanah. Penerapan sistem pertanian organik juga mampu memperbaiki karakteristik sifat biologi tanah dengan meningkatkan res- pirasi tanah, jumlah mikroorganisme tanah, dan populasi cacing tanah (Margolang et al. 2015).

Meskipun terjadi peningkatan permintaan yang besar terhadap produk organik, namun pertanian organik belum sepenuhnya memasyarakat, baik oleh petani sendiri maupun oleh pemerintah yang telah mencanangkan program kembali ke organik (go organic) pada tahun 2010. Menurut Charina et al. (2018), dari aspek petani penerapan sistem pertanian organik dipengaruhi oleh tingkat pendidikan petani, keikusertaan petani dalam kegiatan penyuluhan, persepsi petani terhadap keuntungan relatif, persepsi petani terhadap kerumitan, dan observability sistem pertanian organik.

Penelitian terkait urin kelinci telah di lakukan oleh Badan Penelitian Ternak yang memperlihatkan urin kelinci mengandung unsur $\mathrm{N}, \mathrm{P}$, dan K masing-masing sebesar 2,72; 1,1; dan 0,5\% lebih tinggi dari pada kotoran dan urin ternak lain seperti sapi, kerbau, domba, kuda, babi, bahkan ayam. Menurut Sholikhah et al. (2018), urin kelinci yang sudah diolah menjadi pupuk organik tidak hanya bermanfaat untuk pertumbuhan tanaman dan mengembalikan kesuburan lahan, tetapi juga untuk mengurangi biaya yang harus di keluarkan dalam kegiatan usaha tani. Bahkan menurut Supartha et al. (2012), penambahan pupuk organik cair pada pertanaman padi sistem pertanian organik mampu meningkatkan hasil gabah kering panen sebesar 4,4-17,4\%.

Program pengabdian kepada masyarakat ini dilakukan dalam upaya meningkatkan pemahaman petani terhadap sistem budi daya padi organik melalui demplot budi daya padi organik menggunakan POC urin kelinci, introduksi ternak kelinci, dan pelatihan pembuatan POC urin kelinci.

\section{METODE PELAKSANAAN KEGIATAN}

\section{Lokasi, Waktu, dan Partisipan Kegiatan}

Lokasi kegiatan pengabdian kepada masyarakat dilakukan di Kelurahan Bobosan, Kecamatan Purwokerto Utara, Kabupaten Banyumas yang terletak pada ketinggian tempat 102,48 mdpl pada bulan Mei-September 2020. Kegiatan ini melibatkan Kelompok Ngudi Tani yang banyak melakukan budi daya pada tanaman padi. Anggota kelompok tani ini berjumlah 20 orang, namun untuk kegiatan demplot menggunakan lahan dari 5 orang petani, sedangkan untuk 
penyuluhan dan pelatihan pembuatan POC dan aplikasinya dihadiri oleh sebagian besar anggota.

\section{Bahan dan Alat}

Bahan yang digunakan dalam kegiatan ini untuk mendukung pelaksanaan kegiatan antara lain benih padi varietas Situ Bagendit, POC urin kelinci, urin kelinci, buah maja, molase, air leri (cucian beras), serta kayu, paku, dan kawat strimin untuk pembuatan kandang kelinci. Alat yang digunakan dalam kegiatan ini meliputi peralatan pertukangan, ember besar, jerigen, selang, sprayer, pisau, gunting, dan alat tulis.

\section{Metode Pelaksanaan Kegiatan}

Metode kegiatan yang digunakan adalah belajar sambil bekerja (learning by doing) dengan model pembelajaran dan pelatihan orang dewasa (andragogik dan atau partisipatif), yaitu: 1) Attitude (cara dan pola berkipikir) dengan sasaran bidang afektif; 2) Habit (perilaku atau kebiasaan) dengan sasaran bidang afektif; 3) Knowledge (tingkat pengetahuan) dengan sasaran bidang kognitif; dan 4) Peningkatan skill dengan sasaran psikomotorik. Penyuluhan dan pelatihan melalui praktik dan demplot difokuskan pada cara kerja dan teknik yang benar dalam mendukung produksi padi yang berkelanjutan.

Melalui metode ini petani dituntut berpartisipasi aktif mengidentifikasi permasalahan dalam kegiatan budi daya padi dengan membandingkan kondisi aktual dengan kondisi ideal dalam sistem budi daya organik. Peran aktif ini kemudian mengarahkan palur berpikir petani menuju sebuah kesimpulan akan pentingnya penerapan sistem pertanian organik, kendala yang mungkin dihadapi dalam penerapan sistem ini, dan bagaimana alternatif solusinya.

\section{- Evaluasi pemahaman petani terhadap sistem pertanian organik}

Seluruh petani terlebih dahulu dinilai melalui pre-test untuk mengetahui tingkat pengetahuan dan pemahaman tentang padi organik dan POC urin kelinci. Kegiatan dilanjutkan dengan praktik dan demplot. Selama praktik dan demplot berlangsung dilakukan pendampingan untuk meningkatkan pengetahuan dan pemahaman petani terhadap padi organik dan urin kelinci. Kegiatan evaluasi dilakukan setelah pelatihan dengan metode yang sama (post-test) untuk mengetahui keberhasilan peningkatan pengetahuan dan pemahaman petani terhadap kegiatan yang sudah dilakukan.

\section{- Penyuluhan dan pelatihan pembuatan POC urin kelinci}

Pelatihan pembuatan POC dikuti oleh seluruh anggota kelompok Ngudi Tani Kelurahan Bobosan dan komunitas peternak kelinci. Tim pengabdi memberikan pelatihan cara pembuatan POC agar urin kelinci tidak hanya terbuang percuma sebagai limbah, tetapi bisa dimanfaatkan sebagai pupuk. Bahan yang digunakan dalam pembuatan POC adalah urin kelinci, air cucian beras, molase, dan buah maja. Bahan tersebut dicampur dan difermentasi kurang lebih dua minggu. POC dikategorikan berhasil jika mengeluarkan aroma seperti tape atau tidak berbau busuk. Pelatihan diadakan pada tanggal 25 Juli 2020, di mana tingkat keberhasilan kegiatan pelatihan ini dapat dilihat berdasarkan hasil kuesioner pada akhir rangkaian pengabdian.

\section{- Demplot aplikasi POC urin kelinci dalam budi daya padi organik}

Demplot pemanfaatan POC untuk budi daya padi dilaksanakan oleh 5 orang petani contoh yang merupakan anggota kelompok dengan luas lahan masing-masing $1400 \mathrm{~m}^{2}$. Dari 5 petani contoh, 3 orang petani dalam pemupukannya menerapkan hanya menggunakan POC urin kelinci dengan 5 kali aplikasi dan varietas yang ditanam adalah Inpari 42. Sedangkan 2 orang petani lainnya menggunakan POC urin kelinci sebanyak 2 kali aplikasi ditambah pupuk Phonska, dan varietas yang ditanam adalah Situ Bagendit.

\section{- Pengembangan budi daya kelinci}

Pengadaan ternak kelinci diberikan kepada 5 orang petani contoh yang lahannya dijadikan demplot. Pengadaan ternak dimulai pada tanggal 23 Juni 2020, sedangkan pelatihan dilakukan dengan mengunjungi peternak kelinci pada tanggal 12 Juli 2020 di Desa Kebocoran, Kecamatan Kedungbanteng.

Pelatihan yang diberikan antara lain pembuatan kandang, cara pemberian pakan, jenis pakan, pembersihan kandang, penanganan ternak yang sakit, pengawinan, penyiapan persalinan, dan pemeliharaan bayi kelinci, serta pemisahan atau sapih. Keberhasilan pelatihan diukur dari keberhasilan ternak kelinci yang dijalankan oleh petani contoh dilihat dari jumlah kelinci yang dimiliki saat akhir kegiatan. 


\section{Metode Pengumpulan Data}

Evaluasi terhadap pemahaman petani terhadap sisterm pertanian organik dilakukan dengan metode pre- dan post-test. Sebelum diberikan penyuluhan dan pendampingan petani diberikan beberapa pertanyaan terkait sistem pertanian organik. Hasil pre-test ini menjadi acuan penentuan metode pelaksanaan dan materi yang akan diberikan pada penyuluhan maupun pendampingan. Setelah selesai penyuluhan dan pendampingan, dilakukan post-test untuk mengukur dampak kegiatan terhadap khalayak sasaran.

Pengukuran hasil dari implementasi sistem pertanian organik dengan aplikasi POC urin kelinci diukur dengan mengukur hasil panen (bobot gabah kering panen yang dihasilkan) antara petani demplot yang hanya menggunakan POC urin kelinci dan aplikasi POC urin kelinci dikombinasikan dengan pupuk sintentik.

\section{Pengolahan dan Analisis Data}

Pengolahan dan analisis data dilakukan menggunakan metode deskriptif kualitatif dan kuantitatif, yaitu dengan membandingkan data sebelum dengan sesudah kegiatan serta angka perkembangan yang terjadi khususnya pada kegiatan pengembangan ternak kelinci. Data yang didapat dari pre- dan post- test direkapitulasi dan ditentukan persentase sebaran pilihan jawaban petani (responden). Pada akhir periode dilakukan pembandingan nilai antara hasi pre- dan post- test. Apabila terjadi peningkatan nilai berarti terdapat pengaruh kegiatan terhadap petani. Tingkat keberhasilan peningkatan pengetahuan dan pemahaman petani diukur menggunakan kriteria sebagai berikut: a) Jika $40 \%$ petani memahami kegiatan yang dilakukan = kurang; b) Jika $40-59 \%$ petani memahami kegiatan yang dilakukan = sedang; $c$ ) Jika $60-79 \%$ petani memahami kegiatan yang dilakukan = baik; dan d) Jika > 80\% petani memahami kegiatan yang dilakukan = sangat baik.

\section{HASIL DAN PEMBAHASAN}

\section{Penyuluhan dan Pemahaman Petani terhadap Sistem Pertanian Organik}

Kegiatan penyuluhan dan pelatihan sedianya akan dilaksanakan secara massal namun terkendala adanya pandemi Covid-19. Penyuluhan awal dilaksanakan terbatas pada lima petani yang melaksanakan demplot dengan membekali pemahaman tentang konsep pertanian organik, terpadu dan ramah lingkungan. Pada kegiatan ini disampaikan rencana kegiatan tindak lanjut berupa pengadaan ternak kelinci, demplot padi organik, dan pelatihan pembuatan POC urin kelinci. Masing-masing petani demplot tersebut diberikan satu paket bahan pembuatan kandang kelinci sederhana berkapasitas 10 ekor dan POC urin kelinci yang sudah jadi sebanyak 25 L. Pengadaan ternak kelinci dilaksanakan setelah petani selesai membuat kandang dan mendapatkan pembekalan teknik budi daya kelinci.

\section{Demplot Sistem Pertanian Organik}

Kegiatan ini dilaksanakan untuk menunjukkan potensi penggunaan pupuk organik cair (POC) urin kelinci sebagai pengganti pupuk kimia. Dalam pelaksanaan demplot terdapat lima orang petani contoh yang menerapkan penggunaan POC urin kelinci sebagai pemupukan dalam budi daya padi. Lahan yang digunakan sebagai demplot seluas $1400 \mathrm{~m}^{2}$. Perlakuan pemupukan yang diterapkan pada lahan demplot adalah penggunaan POC urin kelinci dengan intensitas penyemprotan lima kali selama budi daya padi. Dosis yang digunakan adalah $100 \mathrm{~mL}$ dalam tiap liter air. POC yang dibutuhkan untuk sekali aplikasi pada lahan 1 sangga ( 5 ubin=70 $\mathrm{m}^{2}$ ) adalah $140 \mathrm{~mL}$ dan apabila disetarakan ke satuan luas hektar berarti membutuhkan $20 \mathrm{~L}$.

Dari lima orang petani contoh, dua orang petani juga menambahkan pupuk, yaitu Phonska. Data terkait demplot sistem pertanian organik berupa nama petani contoh, jumlah aplikasi POC, jenis varietas, dan hasil ditunjukkan pada Tabel 1. Selama pelaksanaan demplot, didapatkan respons positif dari petani, yaitu testimoni yang menyatakan bahwa tanaman dengan aplikasi POC urin kelinci memiliki performa yang lebih baik.

Berdasarkan informasi dari petani contoh, harga jual gabah dari lahan yang mengaplikasikan POC urin kelinci lebih tinggi dari harga jual gabah pada umumnya. Petani contoh atas nama Pak Sitam mendapatkan hasil paling rendah karena tanaman padinya terserang hama tikus dan burung. Hal tersebut bisa terjadi dikarenakan periode tanamnya lebih awal dibandingkan petani sekitar. Tingginya hasil yang diperoleh pada sistem budi daya organik menggunakan POC urin kelinci tersebut juga didukung dari hasil pengabdian yang dilakukan di Desa Piasa Kulon, bahwa aplikasi POC urin kelinci menunjukkan hasil terbaik dengan 
Tabel 1 Data demplot pertanian organik

\begin{tabular}{llccc}
\hline Nama petani & Varietas & Aplikasi POC & Pupuk kimia & Hasil (GKP) \\
\hline Suroso & Inpari 42 & $5 \mathrm{kali}$ & - & $880 \mathrm{~kg}$ \\
Sitam & Inpari 42 & $5 \mathrm{kali}$ & - & $460 \mathrm{~kg}^{*}$ \\
Ghofur & Inpari 42 & $5 \mathrm{kali}$ & - & $600 \mathrm{~kg}$ \\
Sohib & Situbagendit & $3 \mathrm{kali}$ & Phonska & $750 \mathrm{~kg}$ \\
Yono & Situbagendit & $2 \mathrm{kali}$ & Phonska & $700 \mathrm{~kg}$ \\
\hline
\end{tabular}

Keterangan: hasil per 25 sangga, 1 sangga $=70 \mathrm{~m}^{2} ;{ }^{*}=$ terserang hama tikus.

produksi 6,02 t/ha dibandingkan hasil padi yang diperoleh secara umum dari penerapan sistem padi organik yaitu berkisar antara 4,6-6,0 t/ha (Ahadiyat et al. 2019).

Petani demplot selain mengaplikasikan POC urin kelinci pada tanaman padi juga mengaplikasikan POC urin kelinci pada tanaman kacang panjang yang ditanam di pematang. Tanaman kacang panjang juga menunjukkan hasil yang lebih baik dibandingkan tanpa aplikasi POC urin kelinci. Pemberian pupuk organik cair dari urin kelinci dengan konsentrasi 8-32 mL/L yang diaplikasikan sebanyak 8 kali pada tanaman kailan dapat meningkatkan pertumbuhan dan produksi tanaman meliputi bobot basah tanaman, tinggi tanaman, panjang akar tanaman, dan luas daun tanaman (Choliq et al. 2019). Pemberian POC urin kelinci menunjukkan hasil yang paling baik terhadap pertumbuhan tanaman mentimun, yaitu pada panjang tanaman dan diameter batang dengan hasil masing-masing 132,78 cm dan 0,31 cm (Handayani et al. 2020). Penggunaan urin kelinci yang sudah diolah menjadi pupuk organik dan pestisida organik tidak hanya bermanfaat untuk pertumbuhan tanaman dan mengembalikan kesuburan lahan, tetapi juga untuk mengurangi biaya yang harus dikeluarkan dalam kegiatan usaha tani serta lebih ramah lingkungan (Sholikhah et al. 2018).

Berdasarkan informasi yang diperoleh dari petani contoh, POC urin kelinci tidak hanya meningkatkan hasil pada pertanaman padi tetapi juga kacang panjang dan rumput pakan ternak. POC urin kelinci efektif untuk mengendalikan hama pada tanaman padi, cabai, kacang panjang, dan pepaya. Meskipun hasil yang diperoleh lebih tinggi, tetapi efek lain dari aplikasi POC urin kelinci yang dikeluhkan oleh petani, yaitu buah cabai beraroma tidak enak (bau urin), buah pepaya bertekstur tidak baik dan rasa tidak enak, jerami padi yang digunakan sebagai pakan tidak disukai ternak (sapi), dan rumput tidak disukai ternak (kelinci). Sejauh ini, aplikasi POC urin kelinci diaplikasikan dengan cara disemprotkan, sehingga kemungkinan besar hal tersebut yang memberikan efek samping terutama terkait aroma. Selain hal tersebut, kemungkinan besar POC urin kelinci yang diaplikasikan oleh petani belum terfermentasi secara sempurna.

\section{Pengembangan Budi Daya Kelinci}

Petani demplot juga dibekali ternak kelinci dengan harapan dapat menjadi contoh dalam penerapan sistem pertanian terpadu. Keterpaduan ini diperoleh dengan memanfaatkan kotoran kelinci baik padat maupun cair sebagai pupuk pada budi daya padi yang dilakukan. Pemilihan kelinci sebagai paduan budi daya padi pada kelompok Ngudi Tani adalah potensi perkembangbiakan kelinci yang cepat sehingga akan lebih cepat menghasilkan keuntungan. Selain itu, kotoran kelinci memiliki kandungan hara yang tinggi di antara kotoran ternak yang lain. Sumber pakan di wilayah Bobosan juga masih tergolong melimpah, sehingga petani tidak akan kesulitan mendapatkan pakan kelinci.

Melalui budi daya kelinci diharapkan petani mendapatkan substitusi pupuk kimia dari kotoran ternak, sehingga meningkatkan efisiensi usaha taninya. Ternak kelinci juga dapat dijadikan tambahan sumber pendapatan ekonomi bagi petani, mengingat potensi kegagalan usaha tani di wilayah Bobosan dan Purwokerto pada umumnya relatif tinggi akibat hama tikus, burung, dan wereng yang siklusnya sulit diputus.

Jenis kelinci yang diberikan adalah jenis pedaging dari peranakan New Zealand (NZ) dengan pertimbangan kecepatan pertumbuhan dan bobot maksimal yang dapat dicapai lebih tinggi dibanding kelinci jenis lain. Kelinci peranakan New Zealand White memiliki potensi sebagai salah satu ternak alternatif untuk menyumbang kebutuhan daging. Keunggulan yang diperoleh dari pemeliharaan kelinci New Zealand White antara lain tingkat pertumbuhan yang cepat, kualitas karkas, kesuburan, angka kelahiran, dan kemampuan pengasuhan yang baik terhadap anaknya (Widitania et al. 2016).

Sebagai langkah pendukung dalam pengembangan kelinci pada kelompok tani ini, diberikan pelatihan budi daya kelinci yang bekerja sama dengan komunitas peternak kelinci Purwokerto. 
Petani penerima bibit kelinci difasilitasi belajar kepada peternak berpengalaman untuk meminimalkan kegagalan. Introduksi ternak kelinci di kelompok Ngudi Tani Kelurahan Bobosan dapat dilihat pada Gambar 1.

Upaya yang dilakukan untuk mengembangkan ternak kelinci, yaitu petani demplot yang memperoleh bibit kelinci melakukan pengguliran bibit kepada anggota kelompok lainnya setelah bibit tersebut beranak dan telah dilakukan penyapihan. Pengguliran ini diharapkan dapat menjangkau seluruh anggota kelompok sehingga sistem pertanian organik terpadu pada kelompok Ngudi Tani dapat terwujud. Data introduksi ternak kelinci sebagai indikator keberhasilan dalam budi daya kelinci dapat dilihat pada Tabel 2. Petani contoh yang diberikan bibit kelinci ada yang tidak menerapkan pembuatan POC dikarenakan bibit kelinci yang diberikan mengalami kematian $100 \%$.

\section{Pelatihan Pembuatan Pupuk Organik Cair Urin Kelinci}

Pelatihan pembuatan POC urin kelinci dilakukan setelah pengadaan ternak kelinci dan limbah (kotoran ternak) yang dihasilkan cukup banyak. Kegiatan ini diikuti oleh anggota kelompok dan peternak kelinci dari luar desa. Kegiatan pelatihan ini mendapatkan respons yang positif dengan tingkat kehadiran dan antusiasme yang tinggi dari anggota kelompok. Selain itu, peternak kelinci dari luar desa yang hadir mengapresiasi cara pengolahan urin ini dan

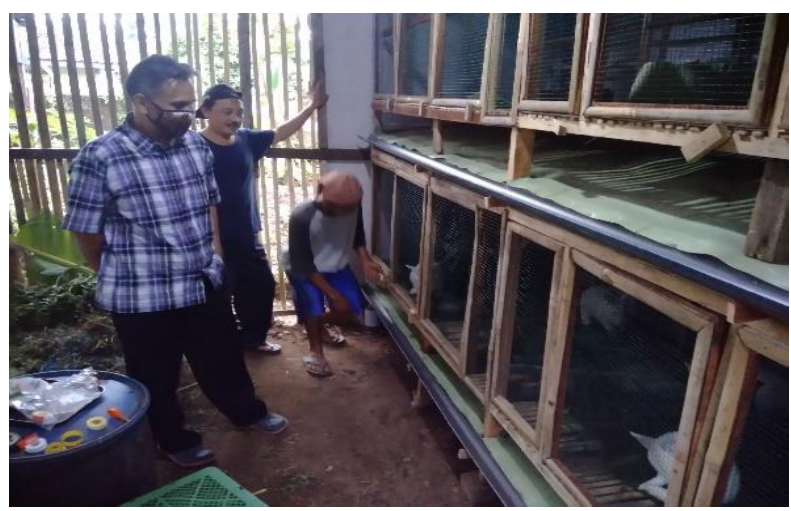

Gambar 1 Introduksi ternak kelinci. mengharapkan adanya penyuluhan serupa di komunitas peternak kelinci. Kegiatan pelatihan pembuatan POC dapat dilihat pada Gambar 2. Apabila ternak kelinci telah berkembang di kelompok dengan populasi ternak yang besar, dapat ditindaklanjuti dengan pembuatan unit pengolahan limbah urin menjadi POC yang bersifat komunal dengan skala besar.

Secara umum, keberhasilan transfer pengetahuan dan teknologi pada kegiatan pengabdian ini diukur menggunakan pre- dan post- test. Petani diminta mengisi kuesioner sebelum dilaksanakan kegiatan pelatihan yang memuat beberapa pertanyaan seputar kegiatan budi daya padi yang biasa dilakukan. Hasil evaluasi petani dalam pemahaman pada sistem pertanian organik pada kelompok Ngudi Tani ditunjukkan pada Tabel 3.

Hasil tes menunjukkan bahwa kegiatan pengabdian meliputi penyuluhan, pelatihan, demplot, dan introduksi ternak berhasil dengan baik meskipun belum mancapai taraf yang diharapkan. Kendala yang paling besar adalah pada anggota petani mitra yang mayoritas belum memiliki komitmen kuat untuk menerapkan sistem pertanian organik. Hal ini terlihat dari lemahnya tindak lanjut kegiatan hasil pelatihan pembuatan POC dan pengembangan ternak kelinci untuk disebarkan ke anggota kelompok tani yang lainnya. Secara umum pengetahuan dan keterampilan petani meningkat terkait budidaya kelinci dan pengolahan urin menjadi pupuk

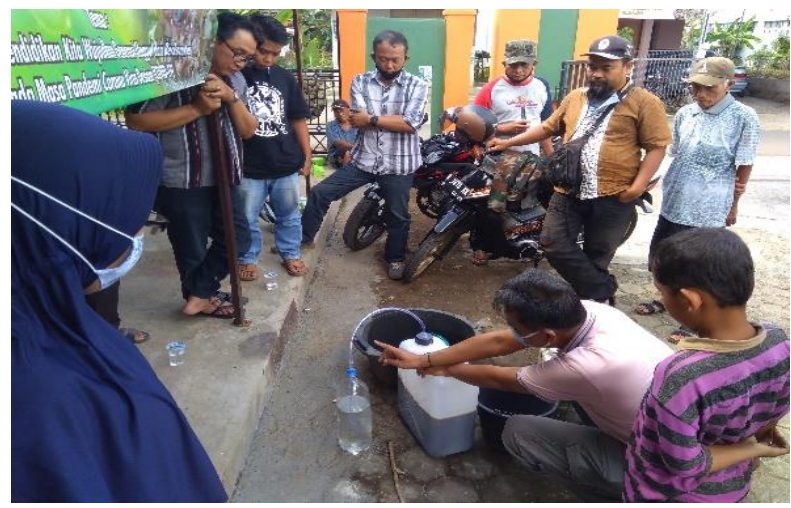

Gambar 2 Praktik pembuatan POC urin kelinci.

Tabel 2 Data introduksi ternak kelinci

\begin{tabular}{ccccccc}
\hline Nama & Jumlah awal & $\begin{array}{c}\text { Jumlah } \\
\text { Kematian }\end{array}$ & $\begin{array}{c}\text { Jumlah } \\
\text { anakan }\end{array}$ & $\begin{array}{c}\text { Kematian } \\
\text { anakan }\end{array}$ & $\begin{array}{c}\text { Populasi } \\
\text { saat ini }\end{array}$ & \multicolumn{2}{c}{ Membuat POC } \\
urin
\end{tabular}


Tabel 3 Hasil evaluasi kegiatan anggota Poktan

\begin{tabular}{lcc}
\hline \multicolumn{1}{c}{ Evaluasi } & Pre-test (\%) & Post-test (\%) \\
\hline Aplikasi pupuk kimia & 100 & 75 \\
Kombinasi pupuk kimia dengan pupuk organik & 25 & 50 \\
Mengetahui cara pembuatan POC & 15 & 100 \\
Menggunakan pestisida kimia & 100 & 75 \\
Mengenal pestisida nabati & 0 & 50 \\
Mengetahui pertanian organik & 45 & 100 \\
Menerapkan pertanian organik & 0 & 40 \\
Tertarik menerapkan pertanian organik & 40 & 75 \\
Mengetahui manfaat pertanian organik & 0 & 50 \\
\hline
\end{tabular}

Keterangan: data berasal dari 20 petani anggota poktan

organik cair meskipun kurang berkelanjutan. Perubahan pola pikir menjadi hal yang krusial dalam penerapan sistem pertanian organik dan proses perubahan ini memang tidak dapat dicapai dalam waktu yang singkat. Hal ini sejalan dengan hasil penelitian (Lesmana \& Margareta 2017) bahwa meskipun pengetahuan petani tentang sistem pertanian organik termasuk kategori tinggi namun petani masih mengalami kesulitan dalam penerapannya secara berkelanjutan.

\section{SIMPULAN}

Pelaksanaan kegiatan pengabdian masyarakat pada Kelompok Ngudi Tani, Kelurahan Bobosan menunjukkan bahwa introduksi POC urin kelinci pada budi daya padi direspons positif oleh petani dibuktikan dengan meningkatnya pemahaman petani hasil dari pre- dan post- test. Petani juga telah memahami dalam pemeliharaan kelinci dan prosedur pengolahan limbah urin kelinci menjadi pupuk organik. Penggunaan POC urin kelinci dengan volume $100 \mathrm{~L} /$ ha yang melalui penyemprotan sebanyak 5 kali selama musim tanam padi mampu mensubstitusi pupuk kimia tanpa menurunkan hasil panen.

\section{UCAPAN TERIMA KASIH}

Pengabdian ini didanai dari dana BLU Universitas Jenderal Soedirman Tahun Anggaran 2020 pada Skema PPM Berbasis Riset. Ucapan terima kasih juga disampaikan kepada Kelompok Ngudi Tani, Kelurahan Bobosan, Kabupaten Banyumas atas kerja samanya selama kegiatan dilaksanakan.

\section{DAFTAR PUSTAKA}

Ahadiyat YR, Hadi SN, Widiyawati I. 2019. Penerapan sistem padi organik dengan aplikasi agens hayati P60 dan urine kelinci di Desa Piasa Kulon Kabupaten Banyumas. Panrita Abdi. 3(1): 80-88.

Charina A, Kusumo RAB, Sadeli AH, Deliana Y. 2018. Faktor-faktor yang Mempengaruhi Petani dalam menerapkan Standar Operasional Prosedur (SOP) sistem pertanian organik di Kabupaten Bandung Barat. Jurnal Penyuluhan. 14(1): 68-78. https://doi.org/ 10.25015/penyuluhan.v14i1.16752

Choliq FA, Martosudiro M, Apriliana QA, Istiqomah. 2019. Pengaruh pemberian urin kelinci terhadap serangan Turnip Mosaic Virus (TuMV) pada tanaman kailan (Brassica oleraceae var. Alboglabra) yang dibudidayakan secara organik. Agroradix. 2(2): 18-31. https://doi.org/10.52166/ agroteknologi.v2i2.1587

Handayani T, Sholihah A, Asmaniyah S. 2020. Pengaruh aplikasi pupuk kandang, NPK dan urine kelinci terhadap pertumbuhan dan produksi dua macam varietastanaman mentimun (Cucumis sativus. L). Agronisma. 8(1): 12-21. https://doi.org/10.36985/ rhizobia.v8i1.70

Lesmana D, Margareta. 2017. Tingkat pengetahuan petani padi sawah (Oryza sativa L.) terhadap pertanian organik di Desa Manunggal Jaya Kecamatan Tenggarong Seberang. Jurnal Pertanian Terpadu. 5(2): 1833. https://doi.org/10.36084/jpt..v5i2.124

Margolang RD, Jamilah, Sembiring M. 2015. Karakteristik beberapa sifat fisik, kimia, dan 
biologi tanah pada sistem pertanian organik. Jurnal Onlie Agroekoteknologi. 3(2): 717-723.

Mayrowani H. 2016. Pengembangan pertanian organik di Indonesia. Forum Penelitian Agro Ekonomi. 30(2): 91-108. https://doi.org/10. 21082/fae.v30n2.2012.91-108

Sholikhah U, Magfiroh IS, Fanata WID. 2018. Pemanfaaatan limbah urine kelinci menjadi Pupuk Organik Cair (POC). Asian Journal of Innovation and Entrepreneurship., 3(2): 204208.
Supartha INY, Wijana G, Adnyana GM. 2012. Aplikasi jenis pupuk organik pada tanaman padi sistem pertanian organik. E-Jurnal Agroekoteknologi Tropika. 1(2): 98-106.

Widitania S, Soepri OY, Lestari MSC. 2016. Korelasi antara bobot badan induk dengan litter size, bobot lahir dan mortalitas anak kelinci New Zealand White. Jurnal IImu-Ilmu Peternakan. 26(2): 42-48. https://doi.org/10. 21776/ub.jiip.2016.026.02.6 